\title{
Consumers' Internal Meaning on Complementary Co-Branding Product by Using Osgood's Theory of Semantic Differential
}

\author{
Rachmat Kriyantono* \\ School of Communication, Universitas Brawijaya, Malang, 65145, Indonesia
}

\begin{abstract}
Objective - The research focuses on applying semantic meaning theory and semantic differential scale to marketing communication, particularly co-branding products strategy, as an external stimulus to the consumers. The research aims to evaluate a hypothesis that co-brands have different meaning from the consumers, however, the consumers would express more positive meaning - evaluation, activity, potency- toward a parent brand.

Methodology - Although co-branding products have been in use for some time, there is surprisingly little quantitative empirical research on the subject.

Findings - A survey on 100 respondents reveals that although co-brands -Avanza and Xenia- have identical products, they have different meaning from the consumers, and the consumers express more positive meaning -evaluation, activity, potency- toward Avanza rather than Xenia.
\end{abstract}

Novelty - It contributes to develop the study of co-branding in Indonesia.

Type of Paper: Empirical

Keywords: Co-branding Product, Indonesia, Marketing Communication, Osgood's Semantic Differential, Semantic Meaning Theory.

JEL Classification: M31, M37.

\section{Introduction}

The Semantic Meaning Theory (Osgood's Theory) is rooted from psychology (Finstuen, 1977; Littlejohn \& Foss, 2009; Strunga, 2014) that focuses on discussing the individuals' perception and cognitive within the meaning of the message and this meaning relates to the attitude and behaviours of the individuals. Stimulus or messages from the outside produce an internal meaning in the minds of individuals and produce a response (Craig, 2007; Griffin, 2012; Littlejohn \& Foss, 2009). Osgood, Suci, and Tannenbaum (1957) expanded the Semantic Meaning Theory by offering a measurement tool called semantic differential. This measurement assumes that one's meaning can be expressed by the use of various adjective words or connotations. The expression of individual's connotations can be grouped into three dimensions of adjective, namely evaluation (good or bad), activity (active or passive), and potency (strong or weak). The three dimensions are also known as semantic space.

\footnotetext{
* Paper Info: Received: November 12, 2016

Accepted: May 18, 2017

* Corresponding author:

E-mail: rachmat_kr@ub.ac.id

Affiliation: School of Communication, Universitas Brawijaya, Indonesia
} 
Osgood stated that the three dimensions of signification (meaning) occur in various contexts, all people, and all concepts (Osgood et al, 1957), including sociology (Strunga, 2014), communication science (Craig, 2007; Griffin, 2012; Littlejohn \& Foss, 2009), educational settings, language and cross-cultural studies (Finstuen, 1977), and marketing/business research (Finstuen, 1977; Khan, 2007; Sharpe \& Anderson, 1972). However, few semantic differential research has been made in business (Finstuen, 1977). "There seems to have been little systematic effort devoted to applying the technique to marketing contexts" (Sharpe \& Anderson, 1972, p. 432). Hence, the current research focuses on applying semantic differential theory to co-branding products strategy, as an external stimulus to the consumers.

\section{Literature Review and research hypothesis}

Many different terms - strategic alliance, joint marketing, co-marketing, joint branding, ingredient marketing and so on- are used to identify a co-branding (Ahn \& Sung, 2012). Co-branding "represents a longterm brand alliance strategy in which one product is branded and identified simultaneously by two brands" (Helmig, Huber, \& Leeflang, 2008, p. 360). "The combining and retaining of two or more brands to create a single product or service." (Leuthesser, Kohli, \& Suri, 2003, p. 36). "Co-branding is the practice of using the established brand names of two different companies for the same physical product" (Cao, 2012).

Co-branding is a relatively new phenomenon in marketing (Guillet \& Tasci, 2010). Norris's (1992) study was considered the first to formulate the benefit of co-branding (Helmig et al, 2008; Srejeesh, 2012) and quantitative empirical research on co-branded products did not begin until 1995 (Helmig et al, 2008). Recently, co-branding is increasingly popular for gaining commercial success (Ahn \& Sung, 2011; Sreejesh, 2012; Singh, Kalafatis, \& Ledden, 2014) and gaining attention from managers and scientists as a form of brand management (Helmig et al, 2008) and has been applied across a range of study in business and management (Ashton \& Scott, 2011). It posits important roles to build brand equity, to enter new markets, to help brands that are not well-known (Clow \& Baack, 2010, p. 62-65), preference, and purchase intention (Kurniawan, Suryoko, \& Listyorini, 2014s). "It is an instrument used by marketers on a wide spectrum, including creating initial awareness, familiarity, and customer loyalty" (Gullet \& Tasci, 2010, p. 143).

It is noted that those roles depend on how the consumers perceive the quality, value, and meaning of the co-brand products so they are not entirely within the control of the marketer (Askegaard \& Bengtsson, 2005; Clow \& Baack, 2010; Finne \& Gronroos, 2009). "How customer perceives co-branding would be a prerequisite to assessing the relative attractiveness of co-branding so that the majority of research focus on the customer perceptions" (Leuthesser et al, 2003, p. 37). Co-branding strategy needs a careful execution because it also has potential risk, such as both brands will suffer if co-branding fails (Clow \& Baack, 2010. Because of this, co-branding strategy needs semantic differential as a measurement to evaluate its impact on consumers.

This current research focuses on how consumers perceive Toyota Avanza and Daihatsu Xenia, as multipurpose vehicles (MPV) that are marketed by two different brands since 2003 (Irawan, 2012; Kurniawan et al., 2014). Although they are top brands, Toyota has higher equity than Daihatsu (Irawan, 2012). Toyota is a parent brand and the owner of Daihatsu (Irawan, 2012). Both vehicles are produced by Toyota Motor Corporation (Gunawanti, 2013). The vehicles were amazing phenomenon because of the cheap price for an MPV. Before they were launched, the queued orders were up to thousands units (Irawan, 2012). The vehicles are identical in the car design, body, specification, and promotion, but, Avanza is more expensive (Gunawanti, 2013). Although they were successful in the top ten sales since they were launched, Avanza has a higher number of sales (Irawan, 2012; Gunawanti, 2013; Sirait, 2016). During 2004-2010, Avanza was ranked the best sold car followed by Xenia and both brands dominated $78 \%$ of the car market. Avanza still became the best sold car, but, Xenia was in $7^{\text {th }}$ rank during 2014-2015 (Murdaningsih, 2016). Avanza kept the position in 2016, Xenia was in $4^{\text {th }}$ rank. Up to January 2017, Avanza was still in the first position while Xenia dropped to $9^{\text {th }}$ (Sirait, 2016).

This phenomenon underpins some literature that a co-branded product receives a more positive evaluation if it incorporates a well-known national product brand (Irawan, 2014; Vaidyanathan \& Aggarwal, 2000), and 
two high equities brand are paired will generate a more positive evaluation for each partnering brand instead of before (Ahn \& Sung, 2012; Washburn, Till, \& Priluck, 2000). The high quality product of the brand partner improves the positive evaluation of the co-branded product (Besharat \& Langan, 2014; Helmig, 2008). Brands with equivalent equity levels shared the benefits of the co-branding equally, while lower equity brands benefited more from the alliance than higher equity partners in the business to business co-branding (Kalafatis et al, 2012). It is assumed that Toyota improved the quality perception of Daihatsu, therefore, both Avanza and Xenia went hand in hand in the early period. In the next periods, however, Avanza was able to survive in the first rank while Xenia downed.

The above description leads to question why there is a different level of sales between co-branding products. As delineated above, it is accepted that co-branding strategy is compatible for gaining profit through creating initial awareness, familiarity, customer loyalty, and, purchase. On the other hand, effective co-branding depends greatly on the consumer perceptions instead of entirely within the control of the marketer (Clow \& Baack, 2010; Askegaard \& Bengtsson, 2005). Hence, the following hypothesis is developed: Both co-brands have different meaning from the consumers and consumers would express more positive meaning toward Avanza rather than Xenia.

This current research contributes to develop the study of co-branding in Indonesia. Although co-branded products have been used for some time, there is surprisingly little quantitative empirical research on the subject (Helmig et al, 2008; Kalafatis et al, 2012).

\section{Research Methodology}

The research used semantic differential that involves three main dimensions: evaluation, activity, and potency. The instruments from Colwell et al. (2008) and Vigneron \& Johnson (2004) were adopted to formulate the research questionnaire. Evaluation is how individuals evaluate co-branding products based on conspicuousness, uniqueness, and quality, while activity is individuals' meaning toward the products and it is represented as hedonism and extended self (Vigneron \& Johnson, 2004) and satisfaction (Colwell et al., 2008). Potency is defined as individuals' meaning based on benefit convenience, decision convenience, and transaction convenience (Colwell et al., 2008).

A survey was conducted with a hundred respondents who were selected by using the convenience sampling. The respondents were the people who have information about the products. The comparison depicted the most favourite products and portrayed whether either brand was dominant or equal to the other in order to assess the brand strength or equity. The researchers achieved a percentage of the mean score towards the maximum score, the index value, which represents the product quality: low quality $(<25 \%)$; medium (up to $50 \%$ ); high/good (up to 75\%); and very high/very good (>75\%) (Kriyantono, 2015). The measurement scales were from Osgood's semantic differential scale with seven points of the scales that expressed verbally two different sets of bipolar adjective: good-bad; high-low; strong-weak. A scale was: good $\ldots, \ldots, \ldots ; \ldots ; \ldots, \ldots, \ldots, \ldots$...bad.

\section{Results and discussion}

As displayed in Table 1, generally, both Avanza and Xenia have a high level of quality although, Avanza has higher index value $(66.96 \%)$ than Xenia $(56.69 \%)$. The index of Xenia (56.69\%) closes to the limit of the high index (50\%). All the three dimensions of Avanza are in the high scores, while Xenia has one dimension (evaluation) is in the medium score. Avanza has higher scores than Xenia in all the three dimensions. For both products, the highest index is potency, followed by activity, and the lowest index is evaluation.

The researcher goes to depict the mean scores of each dimension. Since the dimension of evaluation, both products have the lowest assessment in a sub-dimension of uniqueness. For Xenia, the mean score of this sub-dimension goes to below the average (only 2.97 of 7.00), while Avanza is 3.83. Both brands have the same order for the dimension of activity: the highest mean scores are the hedonism and extended self, followed by 
satisfaction. The research does not find the rank similarity among two products in the dimension of potency. Overall, the highest mean score of Avanza is for the product's ability to create identity as a family car; while Xenia gets the highest mean score for an affordable price for the consumer.

It can be said that the respondents express various meanings on both co-branding products, however, they construct that this co-branding products have the highest quality in potency. For this quality, the products have a mean score on more than 5.00. In general, respondents perceive that this co-branding products have ability to satisfy the consumer's need, cheap, therefore, the products are appropriate for the consumers. The benefit is supported by the high level of ability of the producers to communicate the products' characteristics. It is the essence of marketing communication, that is, "marketing communication should focus more on the receivers and the meaning created by the receiver in the communication process" (Finne \& Gronroos, 2009, p. 181), by delivering messages that contain the consumers' needs about the products benefit and usefulness.

The research reveals that although both co-brands have different meaning from the consumers, consumers express more positive meaning - evaluation, activity, potency- toward Avanza rather than Xenia so that the research hypothesis is accepted. Respondents also perceive that Avanza has more ability to satisfy the consumers' need as a family car so that it is affirmed to be a proper car for the respondents. The higher sales of these co-brands are also determined by the cultural character of the consumers. The Indonesian is extended family culture so they prefer to choose the vehicle that has the ability to transport as many as passengers. This fact proves that all MPV brands in Indonesia have the highest sales (Susanto, 2014). The research also supported previous study that "successful co-branding relationships are a result of strong parent brands, 'fit' between parent brands, and that the alliance is perceived to be worthwhile" (Dickinson \& Heath, 2008, p. 23). Toyota is a strong parent brand for Daihatsu so Xenia is perceived to be a good product.

Table 1. Mean scores of semantic differentials

\begin{tabular}{|c|c|c|c|c|c|c|}
\hline \multirow{2}{*}{$\begin{array}{l}\text { Osgood's } \\
\text { dimensions }\end{array}$} & \multirow[t]{2}{*}{ Sub-dimensions } & \multirow[t]{2}{*}{ Items } & \multicolumn{2}{|c|}{ Avanza } & \multicolumn{2}{|c|}{ Xenia } \\
\hline & & & $\begin{array}{l}\text { Mean } \\
\text { Scores }\end{array}$ & $\begin{array}{l}\text { Max } \\
\text { scores }\end{array}$ & $\begin{array}{l}\text { Mean } \\
\text { Score }\end{array}$ & $\begin{array}{c}\text { Max } \\
\text { Scores }\end{array}$ \\
\hline \multirow[t]{4}{*}{ Evaluation } & Conspicuousness & Product's attractiveness & 4.59 & 7.00 & 3.50 & 7.00 \\
\hline & \multirow[t]{2}{*}{ Uniqueness } & Product's uniqueness & 3.83 & 7.00 & 2.97 & 7.00 \\
\hline & & Product's exclusiveness & 4.22 & 7.00 & 3.21 & 7.00 \\
\hline & Quality & Product's quality & 4.50 & 7.00 & 3.73 & 7.00 \\
\hline \multirow{2}{*}{\multicolumn{3}{|c|}{$\begin{array}{r}\text { Total } \\
\text { Index Value }\end{array}$}} & 17.14 & 28.00 & 13.41 & 28.00 \\
\hline & & & $61.21 \%$ & $100 \%$ & $47.89 \%$ & $100 \%$ \\
\hline \multirow[t]{4}{*}{ Activity } & \multirow{2}{*}{$\begin{array}{l}\text { Hedonism and } \\
\text { extended self }\end{array}$} & Product's creativity & 4.38 & 7.00 & 3.56 & 7.00 \\
\hline & & $\begin{array}{l}\text { Product's ability to create identity } \\
\text { as a family car }\end{array}$ & 5.41 & 7.00 & 4.85 & 7.00 \\
\hline & \multirow[t]{2}{*}{ Satisfaction } & Product's impression & 4.70 & 7.00 & 3.82 & 7.00 \\
\hline & & $\begin{array}{l}\text { Product's ability to create } \\
\text { lovingness }\end{array}$ & 4.25 & 7.00 & 3.01 & 7.00 \\
\hline & & Total & 18.74 & 28.00 & 15.24 & 28.00 \\
\hline & & Index Value & $66.92 \%$ & $100 \%$ & $54.42 \%$ & $100 \%$ \\
\hline \multirow[t]{2}{*}{ Potency } & \multirow[t]{2}{*}{$\begin{array}{l}\text { Benefit } \\
\text { convenience }\end{array}$} & $\begin{array}{l}\text { Product's ability to satisfy the } \\
\text { consumer's need }\end{array}$ & 4.93 & 7.00 & 4.59 & 7.00 \\
\hline & & $\begin{array}{l}\text { Product is appropriate for the } \\
\text { consumers }\end{array}$ & 5.29 & 7.00 & 4.75 & 7.00 \\
\hline
\end{tabular}




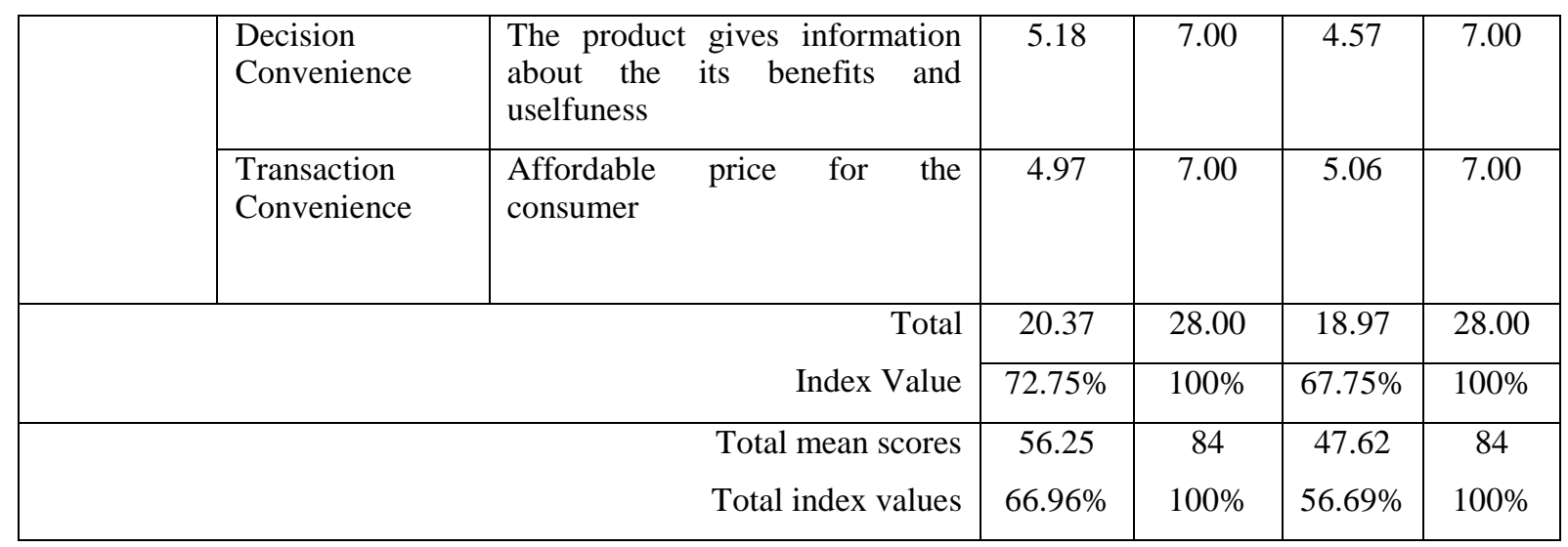

The research also establishes that Xenia has successfully entered the best ten markets because consumer evaluation of co-branded products is dependent upon parent brand attitudes (Dickinson \& Heath, 2008; d'Astous \& Colbert, 2007), in which Toyota that has higher product quality improves the positive evaluation of Xenia, as the weaker brand (Besharat \& Langan , 2014; Norris, 1991, cited in Helmiq, 2008). The research support Kalafatis et al's (2012) study that the companies should consider the brand equity position of potential co-branding partners relative to their own position. If two firms share equal equity positions, they can expect to enjoy equivalent benefits from a co-branding strategy, regardless of how strong the joint equity position is. Adopting Ahn \& Sung (2012), it can be said that the respondents perceive greater fit in functional association terms in which the respondents perceive the attributes and the problem-solving capacity of each product brand is similar or related.

\section{Conclusion}

The research is able to establish the hypothesis that although co-brands have identical products, they have different meaning from the consumers, and the consumers express more positive meaning toward Avanza rather than Xenia. The findings confirm several studies regarding co-branding that the effective co-branding strategy is determined by some factors, such as the consumers' perceptions toward the product itself, the parent brand, and the companies or brands equity position. It is also influenced by the ability of the companies to meet the products with the consumers' needs.

Although the research is able to enrich the study of co-branding in Indonesia, the findings are contingent on a number of limitations that restrict generalizability and represent opportunities for further research. The study investigates co-branding between two brands from the high equity companies, so it is important to extend the research to the established product brands. Future research should also help delineate the generalizability of the present findings and further define the impact of various respondents, not only for the potential consumers but also the current consumers.

\section{Acknowledgements}

The author thanks to Universitas Brawijaya for supporting this publication.

\section{References}

Ahn, H., \& Sung, Y. (2012). A two-dimensional approach to between-partner fit in co-branding evaluations. Journal of Brand Management, 19(5), 414-424.

Askegaard, S., \& Bengtsson, A. (2005). When Hershey met Betty: love, lust and co-branding. Journal of Product \& Brand Management, 14(5), 322-329.

Ashton, A. S., \& Scott, N. (2011). Hotel restaurant co-branding: The relationship of perceived brand fit with intention to purchase. Journal of Vacation Marketing, 17(4), 275-285 
Besharat, A., \& Langan, R. (2014). Towards the formation of consensus in the domain of co-branding: Current findings and future priorities. Journal of Brand Management, 21(2), 112-132.

Cao, Z. (2012). An empirical examination of stock market reactions to introduction of co-branded products. $\mathrm{PhD}$ Dissertation. Graduate Studies of Texas A \& M University.

Clow, K. E., \& Baack, D. (2010). Integrated advertising, promotion, and marketing communications. New Jersey: Pearson Education, Inc.

Colwell, S. R., Aung, M., Kanetkar, V., \& Holden, A. L. (2008). Toward a measure of service convenience: multipleitem scale development and empirical test. Journal of Services Marketing, 22(2), 160-169.

Craig, R, T. (2007). Communication as a field. In Craig, R.T \& Muller, H.L. (Eds.), Theorizing communication: Reading across traditions. London: Sage Publications.

D'Astous, A., \& Colbert, F. (2007). An experimental investigation of the use of brand extension and co-branding strategies in the arts. Journal of Service Marketing, 21(4), 231-240.

Dickinson, S. J., \& Heath, T. (2008). Cooperative brand alliances: How to generate positive evaluations. Australasian Marketing Journal (AMJ), 16(2), 22-38.

Finne, A., \& Gronroos, C. (2009). Rethinking marketing communication: From integrated marketing communication to relationship communication. Journal of Marketing Communications, 15(2-3), 179-195.

Finstuen, K. (1977). Use of Osgood's semantic differential. Psychological reports, 41(3_suppl), 1219-1222.

Gunawanti, P. D. (2013). Pengaruh penetapan harga dan fitur produk terhadap keputusan pembelian (The influence of price and product feature on selling). (Thesis. University of Indonesia, Jakarta).

Griffin, E.M. (2012). communication theory. New York: McGraw Hill.A first look at

Guillet, B. D., \& Tasci, A. D. A. (2010). Travellers' take on hotel-restaurant co-branding: Insights for China. Journal of Hospitality \& Tourism Research, 34(2), 143-163.

Helmig, B., Huber, J. A., \& Leeflang, P. S. (2008). Co-branding: The state of the art.

Irawan, H. (2012). Kijang, Avanza, and Xenia. Frontier Consulting Group. http://www.frontier.co.id/kijang-avanza-danxenia, accessed March 28, 2016.

Kalafatis, S. P., Remizova, N., Riley, D., \& Singh, J. (2012). The differential impact of brand equity on B2B co-branding. Journal of Business \& Industrial Marketing, 27(8), 623-634.

Khan, K. (2007). User experience in mobile phone by using semantic differential methodology. Journal of Marketing Research, 143-150.

Kurniawan, A., Suryoko, S., \& Listyorini, S. (2014). Pengaruh strategi co-branding, brand equity terhadap purchase intention melalui brand preference (The influence of co-branding strategy, brand equity on purchase intention through brand preference). Jurnal Administrasi Bisnis, 3(4), 1-7.

Leuthesser, L., Kohli, C., \& Suri, R. (2003). $2+2=5$ ? A framework for using co-branding to leverage a brand. Journal of Brand Management, 11(1), 35-48.

Littlejohn, S. W., \& Foss. K. W. (2009). Theories of human communication. Jakarta: Salemba Humanika.

Murdaningsih, D. (2016). Mengapa Avanza lebih laku dibanding Xenia (Why avanza better than Xenia). Republika, January 28, 2016.

Osgood, C. E., Suci G.C., \& Tannenbaum, P.H. (1957). The Measurement of meaning. Urbana: University of Illinois Press.

Sharpe, L. K., \& Anderson, W. T. (1972). Concept-scale interaction in the semantic differential. Journal of Marketing Research, 9(4), 432-434.

Singh, J., Kalafatis, S. P., \& Ledden, L. (2014). Consumer perceptions of cobrands: the role of brand positioning strategies. Marketing Intelligence \& Planning, 32(2), 145-159.

Sirait, S. E. (2016). 10 mobil terlaris periode Januari-Oktober 2016 [10 car brands best selling in Januari-October 2016]. news.okezone.com/read/2016/11/22/151547914/10-mobil-terlaris-periode-januari-oktober 2016. Accessed January 9, 2017.

Susanto, A. B. (2014). Mengubah merek, mengubah persepsi [Change the brand, change the perception]. http://www.jakartaconsulting.com/publications/articles/bizmark/mengubah-merk-mengubah-persepsi. $\quad$ The Jakarta Consulting Group, February 1, 2014.

Sreejesh, S. (2012). Consumers' evaluation of co-brand extensions: The effects of concept congruity on the evaluation of co-branded products, analyzing the moderating role of task involvement. International Management Review, 8(1), 21-34. 
Strunga, A. C. (2014). Osgood's semantic differential: A review of the Romanian social sciences literature. Social Sciences and Education Research Review, 2, 22-28.

Vaidyanathan, R., \& Aggarwal, P. (2000), Strategic brand alliances: Implications of ingredient branding for national and private label brands. Journal of Product \& Brand Management, 9(4), 214-228.

Vigneron, F., \& Johnson, W. L. (2004). Measuring perception of brand luxury. Journal of Brand Management, 11(6), 484-507.

Washburn, J. H., Till, T. B., \& Priluck, R. (2000). Co-Branding: Brand equity and trial effects. Journal of Consumer Marketing, 17(7), 591-604. 